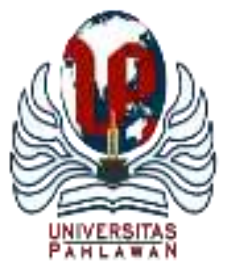

Edukatif : Jurnal Ilmu Pendidikan Volume 3 Nomor 5 Tahun 2021 Halm 3181 - 3188

EDUKATIF: JURNAL ILMU PENDIDIKAN

Research \& Learning in Education

https://edukatif.org/index.php/edukatif/index

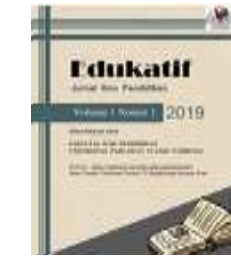

\title{
Penggunaan Gawai pada Pembelajaran Daring terhadap Motivasi Belajar Anak di Sekolah Dasar
}

\author{
Lia Lutviana ${ }^{1 凶}$,Ika Ari Pratiwi ${ }^{2}$, Imaniar Purbasari $^{3}$ \\ Pendidikan Guru Sekolah Dasar, FKIP Universitas Muria Kudus ${ }^{1,2,3}$ \\ E-mail : lialutviana12@ gmail.com ${ }^{1}, \underline{\text { ika.ari@umk.ac.id }}^{2}, \underline{\text { imaniar.purbasari@umk.ac.id }}^{3}$
}

\begin{abstract}
Abstrak
Pembelajaran daring menggunakan gawai membuat keadaan motivasi belajar anak harus diperhatikan, karena kurangnya inspirasi belajar menjadi penghalang untuk mencapai tujuan pembelajaran berbasis web. Tujuan penelitian ini adalah untuk menggambarkan pemanfaatan aplikasi gawai pada anak-anak di Desa Talun dalam pembelajaran berbasis web, dan untuk menggambarkan motivasi belajar anak di Desa Talun dalam pembelajaran berbasis web menggunakan gawai. Penelitian ini ditujukan di Desa Talun, Kayen, Kabupaten Pati dengan subjek penelitian 9 anak SD, 9 wali kelas dan 3 pengajar kelas di SDN Talun 01. Metode pengumpulan informasi yang digunakan meliputi observasi, wawancara dan dokumentasi. Analisis data yang digunakan yaitu deskriptif kualitatif. Hasil penelitian menunjukkan bahwa motivasi belajar anak dalam pembelajaran online dipengaruhi oleh beberapa elemen, yaitu: (1) arahan orang tua dan pengajar, (2) dorongan dalam belajar, (3) latar belakang pendidikan danpekerjaan yang berbeda. Dalam penelitian ini, orang tua dan pengajar harus memberikan bantuan dan manajemen kepada anak-anak ketika belajar daring menggunakan gawai sehingga mereka dapat memperluas motivasi belajar anak yang menjadi kecenderungan dan membentuk pribadi anak.
\end{abstract}

Kata Kunci: Gawai, Pembelajaran Daring, dan Motivasi Belajar.

\begin{abstract}
Online learning using gadgets makes the condition of children's learning motivation to be considered, because the lack of learning inspiration is a barrier to achieving web-based learning goals. The purpose of this study is to describe the use of gadget applications in children in Talun Village in web-based learning, and to describe the learning motivation of children in Talun Village in web-based learning using devices. This research was aimed at Talun Village, Kayen, Pati Regency with research subjects 9 elementary school children, 9 homeroom teachers and 3 class teachers at SDN Talun 01. Information collection methods used included observation, interviews and documentation. The data analysis used is descriptive qualitative. The results of the study indicate that children's learning motivation in online learning is influenced by several elements, namely: (1) direction from parents and teachers, (2) encouragement in learning, (3) different educational and work backgrounds. In this study, parents and teachers must provide assistance and management to children when learning online using devices so that they can expand children's learning motivation which becomes a tendency and shapes the child's personality.
\end{abstract}

Keywords: Gadget, Online Learning and Learning Motivation

Copyright (c) 2021 Lia Lutviana, Ika Ari Pratiwi, Imaniar Purbasari

$\triangle$ Corresponding author

Email : lialutviana12@gmail.com

DOI : https://doi.org/10.31004/edukatif.v3i5.1236

ISSN 2656-8063 (Media Cetak)

ISSN 2656-8071 (Media Online)

Edukatif : Jurnal Ilmu Pendidikan Vol 3 No 5 Tahun 2021 p-ISSN 2656-8063 e-ISSN 2656-8071 
3182 Penggunaan Gawai pada Pembelajaran Daring terhadap Motivasi Belajar Anak di Sekolah Dasar Lia Lutviana,Ika Ari Pratiwi, Imaniar Purbasari

DOI: https://doi.org/10.31004/edukatif.v3i5.1236

\section{PENDAHULUAN}

Pandemi virus corona berdampak signifikan di segala bidang, salah satunya di bidang pendidikan. Pengaturan efektif yang dapat diambil oleh otoritas publik untuk kembali ke efek Coronavirus di bidang pendidikan adalah dengan mengubah pembelajaran tatap muka ke pembelajaran berbasis web. Adaptasi pembelajaran berbasis web atau daring membutuhkan perencanaan yang matang untuk mencapai target pembelajaran yang ideal. Pembelajaran berbasis web mengharapkan anak-anak memiliki pilihan untuk memanfaatkan gawai sehingga tertarik pada pembelajaran daring. Gawai adalah perangkat khusus yang dapat digunakan dan dibawa ke mana saja dengan organisasi yang luas tanpa menggunakan kabel. Pembelajaran daring pada dasarnya merupakan pembelajaran yang dilakukan secara virtual memalui aplikasi virtual yang tersedia(Yunitasari \& Hanifah, 2020).

Pembelajaran dalam jaringan (daring) adalah langkah pembelajaran jarak jauh yang dilakukan dengan maksud dan tujuan dengan cara jarak jauh dan memerlukan organisasi web untuk mencapainya. Aplikasi yang dapat dimanfaatkan untuk membantu pembelajaran daring adalah: whatsapp, zoom, google classroom, dan youtube. Pembelajaran daring dengan memanfaatkan gawai dapat membuat kondisi motivasi belajar anak yang harus dipikirkan. Motivasi belajar yang rendah bisa menjadi bahaya kekecewaan terhadap tujuan pembelajaran daring. Motivasi belajar adalah dorongan dari dalam dan dari luar seseorang untuk terus belajar, sehingga siswa sekolah dasar mendapatkan hasil belajar yang paling ideal. Unsur-unsur yang dapat mempengaruhi motivasi belajar anak dibedakan menjadi dua macam, yaitu unsur dalam dan unsur luar. Unsur dari dalam meliputi: pengetahuan, minat, pertimbangan, motivasi untuk belajar, tekad, sikap, kecenderungan belajar, keadaan dan kesejahteraan. Sedangkan unsur dari luar adalah keluarga, sekolah dan lingkungan sekitar.

Berdasarkan hasil wawancara dari pertemuan yang diarahkan dengan pengajar kelas 5 di SDN Talun 01, sangat mungkin untuk beralasan bahwa pembelajaran daring dapat mempengaruhi anak-anak. Khususnya dalam mengerjakan tugas-tugas yang telah diberikan oleh pengajar. Pemanfaatan gawai pada anak terkadang tidak hanya digunakan untuk menemukan materi atau menyelesaikan suatu tugas yang telah diberikan oleh pendidik, tetapi juga digunakan untuk membuka situs-situs yang menarik bagi anak-anak seperti media online, game, youtube, dll. Keadaan sekarang dapat mempengaruhi berkurangnya motivasi belajar pada anak. (Trinova, 2012) mengungkapkan bahwa bermain merupakan kegiatan serius tetapi di buat asik. Berdasarkan permasalahan yang telah ditemukan, maka upaya yang dapat dilakukan untuk mengatasi penggunaan gawai yang berlebihan pada anak SD di Desa Talun selama pembelajaran daring adalah pengembangan karakter menggunakan gawai secara tepat dan kendala penggunaan gawai. Tujuan penelitian ini yaitu pemanfaatan gawai untuk anak-anak di Desa Talun dalam pembelajaran daring dan menggambarkan motivasi belajar anak di Desa Talun dalam internet yang terbiasa menggunakan gawai.

(Santoso, 2020) menjelaskan bahwa gawai (gadget) cenderung lebih dominan digunakan oleh manusia saat ini. (Kurniawati, 2020) menjelaskan bahwa gawai digunakan untuk mengakses berbagai informasi pengetahuan dalam menggunakan aplikasi, seperti digunakan untuk mencari berbagai informasi mengenai materi yang dianggap sulit. (Chusna, 2017) menjelaskan bahwa gawai merupakan istilah yang berasal dari bahasa Inggris yang mengarah pada alat atau instrumen yang memiliki tujuan dan fungsi spesifik yang berguna. (Marpaung, 2018) mengungkapkan bahwa gawai yaitu telepon genggam atau Handphone (HP) yang berfungsi sebagai alat komunikasi elektronik yang mempunyai kemampuan dasar yang sama dengan telepon konvensional, tetapi dapat dibawa kapan saja dan di mana tidak perlu disambungkan dengan jaringan telepon menggunakan kabel. Mengingat penilaian yang berkualitas di atas, sangat mungkin dianggap bahwa gawai adalah alat khusus yang digunakan dengan maksud dan tujuan dapat dibawa ke mana saja dengan organisasi yang luas tanpa menggunakan tautan untuk membantu berbagai latihan manusia. 
3183 Penggunaan Gawai pada Pembelajaran Daring terhadap Motivasi Belajar Anak di Sekolah Dasar Lia Lutviana,Ika Ari Pratiwi, Imaniar Purbasari

DOI: https://doi.org/10.31004/edukatif.v3i5.1236

(Hanafi, 2020) mengungkapkan bahwa jenis gawai merupakan sebagaimana hiburan audio visual lain yang digunakan untuk bermain meliputi handphone, android touch screen atau playstation. (Rosiyanti \& Muthmainnah, 2018) mengemukakan bahwa gawai yang digunakan biasanya berupa laptop, handphone, dan sebagainya. (Lestari et al., 2015) mengemukakan bahwa terdapat berbagai jenis gawai yang tersebar di Indonesia antara lain smartphone, tablet, komputer, kamera, laptop dan lainnya. Berdasarkan pendapat ahli di atas, dapat disimpulkan bahwa jenis-jenis gawai antara lain: handphone, PC, tablet, iPad, dan iPhone. Mengingat sebagian dari anggapan yang cukup beralasan di atas, dapat disimpulkan bahwa jenis-jenis gawai meliputi handphone, android touch screen, tablet, ipad, dan iPhone yang berguna untuk membantu kegiatan manusia khususnya secara online menggunakan jaringan.

Pembelajaran daring sampai sekarang umumnya dimanfaatkan dalam pembelajaran. (Syarifudin, 2020) menjelaskan bahwa pembelajaran daring adalah pembelajaran yang dilakukan dilakukan secara seara jarak jauh melalui online menggunakan aplikasi virtual dengan tetap memperhatikan kompetensi yang akan diajarkan. (Santika, 2020) menyatakan bahwa pembelajaran daring merupakan pembelajaran yang dilaksanakan sebagai langkah yang tepat untuk mengantisipasi dan menekan angka penularan virus Covid-19 sehingga siswa tidak akan ketinggalan pelajaran sebagaimana yang telah direncanakan. Penelitian yang telah diselesaikan adalah dengan persepsi langsung, khususnya melalui whatsapp dan google classroom pada anak di Desa Talun untuk menentukan motivasi belajar yang dibedakan dengan pencapaian penanda motivasi belajar tersebut. (Yunitasari \& Hanifah, 2020) mengungkapkan bahwa pembelajaran online sangat mempermudah pelajar dalam mengikuti pembelajaran daring, seperti yang sudah pernah diterapkan saat ini ketika banyak sekolah yang diliburkan karena bertujuan untuk mencegah penyebaran Covid-19 dan diganti dengan menggunakan pembelajaran online. (Santika, 2020) menguraikan bahwa terdapat kelebihan pembelajaran daring meliputi, (1) pembelajaran tidak perlu adanya ruang kelas, (2) guru tidak perlu ada tatap muka di kelas, (3) tidak terbatas ruang dan waktu. (Firyal, 2020) menguraikan bahwa terdapat kelebihan pada pembelajaran daring yang menjadikan siswa efektif dalam belajar karena pembelajaran tidak mengakibatkan kelelahan, menyenangkan, dan mendapatkan pengalaman baru. Selain terdapat kelebihan, pembelajaran daring juga mempunyai beberapa kekurangan diantaranya menurut (Anugrahana, 2020) yaitu kurang maksimal keterlibatan siswa dalam pembelajaran daring yang dapat dilihat dari hasil keterlibatan siswa ketika mengikuti pembelajaran daring secara penuh dari awal hingga akhir pembelajaran.

(Lee \& Martin, 2017) mengungkapkan bahwa motivasi adalah dorongan yang memberikan kegiatan perbaikan yang ditunjuk dengan cara yang ideal, sehingga latihan perubahan menjadi bagian penting dalam mencapai suatu motivasi. (- \& -, 2019) mengungkap bahwa motivasi merupakan kekuatan (energi) yang dapat menimbulkan tingkat kemauan untuk melaksanakan suatu kegiatan. (Miftahussaadah \& Subiyantoro, 2021) menyatakan bahwa motivasi yaitu suatu rangkaian upaya yang digunakan untuk memberikan kondisi tertentu agar seseorang mau melakukan sesuatu. Mencermati sebagian dari anggapan di atas, sangat mungkin beralasan memperoleh motivasi merupakan suatu dorongan dari dalam dan dari luar diri seseorang untuk terus mewujudkan agar anak memperoleh hasil belajar yang ideal. Motivasi belajar harus memiliki pilihan untuk memacu diri sendiri sebelum membujuk orang lain, motivasi harus memiliki fokus yang tepat, jelas dan poin demi poin.

Setelah peneliti melakukan kajian-kajian tentang literasi jurnal, maka bisa diadakan penelitian mengenai bagaimana penggunaan gawai pada motivasi belajar anak SD guna menjawab bagaimana pandangan guru, orang tua dan siswa tentang pembelajaran daring dengan menggunakan gawai pada motivasi belajar anak usia SD di Desa Talun Kecamata Kayen Kabupaten Pati. Situasi atau keadaan sekarang ini dengan menerapkan pembelajaran yang berbeda dengan sebelumnya yaitu yang semula tatap muka di kelas berubah menjadi sistem online. 
3184 Penggunaan Gawai pada Pembelajaran Daring terhadap Motivasi Belajar Anak di Sekolah Dasar Lia Lutviana,Ika Ari Pratiwi, Imaniar Purbasari

DOI: https://doi.org/10.31004/edukatif.v3i5.1236

Fokus pada penelitian ini adalah penggunaan gawai pada motivasi belajar anak usia SD. Penelitian ini bertujuan untuk mengetahui penggunaan gawai pada pembelajaran daring terhadap motivasi belajar anak pada masa pandemi Covid 19 saat ini terjadi.

\section{METODE PENELITIAN}

Jenis penelitian yang diarahkan dalam penelitian ini adalah kualitatif deskriptif dengan menggunakan metode pengumpulan informasi observasi, wawancara dan dokumentasi. Informan utama dalam penelitian ini adalah anak usia sekolah dasar, orang tua wali, dan pengajar. Wilayah penelitian ini berada di Desa Talun, RT 01 RW 03, Kecamatan Kayen, Kabupaten Pati. Analisis data dalam penelitian ini menggunakan strategi menurut Milles dan Hubermas dalam (Rijali, 2019) yang terdiri dari tiga komponen, meliputi reduksi data, display data, dan kesimpulan. Pemeriksaan keabsahan data dalam penelitian, peneliti menerapkan teknik referensi yang peneliti peroleh selama penelitian meliputi jurnal penelitian, jawaban responden yang berguna untuk menguji dan mengoreksi hasil penelitian yang telah dilaksanakan. Informasi yang didapat akan dikumpulkan dan diselidiki informasinya untuk diperkenalkan secara ilustratif karena pemeriksaan yang memiliki nilai ketepatan dan kemutakhiran dalam menyajikan data kemudian ditarik kesimpulan.

\section{HASIL DAN PEMBAHASAN PENELITIAN}

\section{Penggunaan Aplikasi Gawai pada Anak di Desa Talun dalam Pembelajaran Daring}

Pandemi virus corona yang berdampak pada pendidikan memerlukan penyesuaian ukuran pengajaran dan pembelajaran. Dampak dari pembelajaran daring salah satunya adalah pendidik tidak dapat memberikan pembelajaran karakter seperti yang diterapkan di sekolah. Keadaan saat ini sangat mempengaruhi kepribadian anak yang hanya berpikir bahwa anak tersebut telah melakukan tugas dari pengajar. Bagaimanapun, pada umumnya usaha yang telah diberikan oleh pengajar benar-benar dilakukan oleh wali, pelatih atau mencari jawaban di web. Sehingga tidak menjunjung tinggi ukuran pembelajaran yang valid. Gawai adalah perangkat khusus yang dapat dibawa, digunakan di mana saja dan kapan saja. Masa sekarang ini, IPTEK berkembang sangat pesat, menurut (Radliya et al., 2017) mengungkapkan bahwa hampir semua masyarakat sudah mampu untuk mengoperasikan gawai di mana saja. Penggunaan gawai yang tidak wajar dapat berdampak buruk pada anak-anak. Dampak tersebut dapat berupa akibat yang merugikan atau dampak yang positif. Akibat buruk yang ditimbulkan oleh penggunaan gawai yang tidak wajar antara lain: a) gangguan kesehatan mulai dari otak, mata dan tangan; b) motivasi belajar anak mungkin berkurang; c) pergantian peristiwa dan ketergantungan psikologis yang lemah; d) sikap dan tingkah laku anak menjadi tertutup dan tidak dapat didekati. Sementara itu, dampak positif penggunaan perangkat antara lain: a) memperluas informasi, pengetahuan, dan data dengan jangkauan yang lebih luas dan mendunia; b) bekerja dengan korespondensi jarak jauh; c) gawai memberikan pengalihan dan kebangkitan kepada kliennya; d) meningkatkan jargon anak-anak, melatih daya ingat dan pemahaman anak-anak dalam informasi karena aplikasi-aplikasi yang kekinian gambar, rekaman dan musik yang memperluas motivasi belajar anak-anak.

Penggunaan gawai dalam mengadaptasi pembelajaran daring sangat membutuhkan peran para pengajar dan orang tua wali, karena, seandainya mereka tidak bekerja sama antara para pendidik dan orang tua wali, anak-anak akan terpengaruh oleh penggunaan gawai yang negatif. Pelaksanaan pembelajaran daring yang kuat membutuhkan sebuah aplikasi yang menjunjung tinggi penggunaan gawai dan harus diakses oleh internet untuk membina komunikasi antara anak-anak dan pendidik. Penggunaan gawai dapat dimanfaatkan dalam pembelajaran daring bagi anak usia SD di Desa Talun khususnya Handphone (Hp) dengan bantuan aplikasi whatsapp dan google classroom untuk absen, mengirim tugas, materi dan mengumpulkan tugas anak yang telah selesai. 


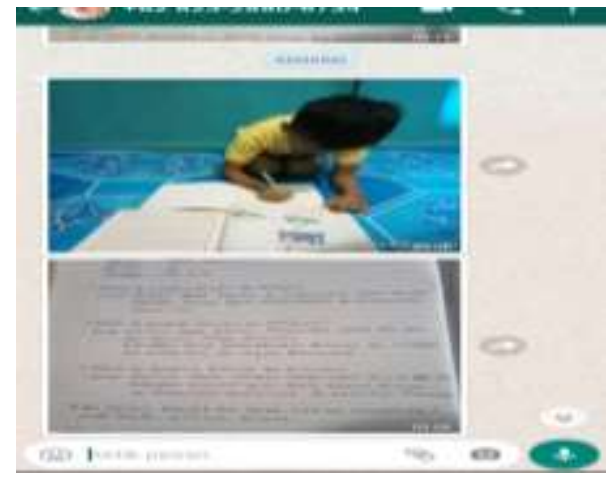

Gambar 1. Pembelajaran Daring Melalui Aplikasi WhatsApp

Berdasarkan gambar di atas, anak mengumpulkan tugas secara online melalui aplikasi whatsapp. Pengajar biasanya meminta bukti foto dari tugas anak-anak dan foto mengerjakan tugas sebagai laporan yang akan dikirim dari guru mereka. Pendidik kemudian, kemudian menegaskan kepada anak itu bahwa tugas telah diterima dan meminta untuk menunggu hasil evaluasi selesai. Bermacam-macam tugas anak-anak yang ideal biasanya dipengaruhi oleh pengawasan orang tua di rumah saat belajar daring.

\section{Motivasi Belajar Anak di Desa Talun dalam Pembelajaran Daring Menggunakan Gawai}

Pembelajaran daring dengan memanfaatkan gawai menjadikan motivasi belajar anak untuk dipikirkan. Karena motivasi belajar yang rendah anak adalah kurang mampu dalam mencapai tujuan pembelajaran berbasis web. Peningkatan motivasi belajar merupakan dukungan dari dalam dan dari luar individu, sehingga seorang anak, khususnya siswa Sekolah Dasar (SD) memperoleh hasil belajar yang paling ideal dengan motivasi belajar. Faktor internal meliputi: wawasan, kecerdasan, pertimbangan, motivasi untuk belajar, kemantapan, disposisi, kecenderungan belajar, keadaan dan kesejahteraan. Komponen luar meliputi: keluarga, sekolah dan daerah setempat. Ciri motivasi menurut (Darmawati, 2017) menguraikan bahwa jika siswa rajin mengerjakan tugas, ulet dalam memecahkan masalah dan hambatan. Hasil penelitian dari informasi yang diperoleh para ilmuwan dalam penelitian ini menemukan bahwa motivasi belajar anak sangat dipengaruhi oleh perhatian dan bantuan wali ketika anak-anak belajar. Bantuan untuk anak saat mengambil bagian dalam pembelajaran daring sangat penting karena itu akan menjadi kebiasaan dan membentuk kepribadian anak.

Berdasarkan observasi yang telah dilakukan oleh peneliti adalah tugas dan tingkat pengajaran wali sangat mempengaruhi perkembangan motivasi belajar anak sehingga anak akan memiliki tujuan dan merasa benar-benar fokus sehingga efeknya motivasi belajar anak akan mengalami kenaikan. Wali atau orang tua yang mengisi sebagai pebisnis dan pedagang dapat fokus pada anak-anak mereka ketika pembelajaran daring dapat diterima karena mereka dapat melakukan pengawasan dan memiliki energi yang cukup untuk anak-anak mereka. Sementara itu, wali atau orang tua yang mengisi sebagai buruh atau pekerja berdampak pada tidak adanya pengawasan terhadap anak saat belajar online, sehingga motivasi anak bisa berkurang. Penemuan pertemuan dengan wali dengan dasar pendidikan yang tinggi terikat untuk menerapkan kecenderungan terlatih ketika mengarahkan pembelajaran daring sehingga sangat mempengaruhi anak-anak. Wali yang memiliki daya belajar rendah kurang memerhatikan anak-anaknya saat belajar online sehingga motivasi belajar mereka berkurang. (Yulianingsih et al., 2020) menjelaskan bahwa inklusi orang tua sangat penting karena berdampak pada prestasi seorang anak. Pelibatan wali atau orang tua dalam pembelajaran berdampak pada peningkatan kemampuan, keilmuan, inspirasi, dan prestasi anak. Motivasi belajar mengambil bagian penting dalam memberdayakan kegembiraan anak sambil mengambil minat dalam pembelajaran daring. Latihan orang tua yang seharusnya dapat memperluas motivasi belajar anak adalah dengan menyisihkan upaya untuk membantu anak dalam mengerjakan tugas-tugas online yang telah diberikan oleh pengajar. Menurut penilaian (- \& -, 2019) ditemukan bahwa motivasi memiliki fungsi atau kegunaan yang penting dalam belajar, karena motivasi akan menentukan suatu ketekunan dalam usaha belajar yang dilakukan siswa. 


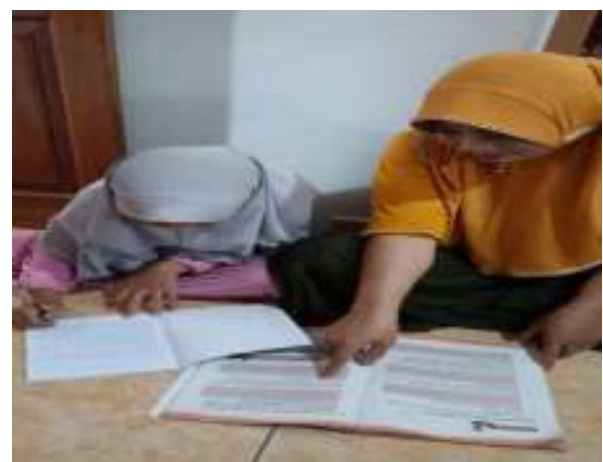

Gambar 2. Dorongan dan Kebutuhan Belajar

Dilihat dari gambar di atas, PI memiliki semangat dan dorongan yang tinggi untuk mengerjakan tugastugas online yang telah diberikan oleh pengajar. Siswa terlihat energik dalam menanggapi pertanyaan yang diberikan oleh pengajar dengan mencari aset pembelajaran yang sesuai dengan materi pada pertanyaan yang diberikan oleh pengajar. Semangat PI untuk belajar ditopang oleh wali atau orang tua yang secara konsisten memberi dorongan PI saat melakukan tugas-tugas di web. Wali atau orang tua juga membatasi penggunaan gawai untuk anak-anak saat belajar daring, yaitu gawai harus diberikan kembali kepada wali atau orang tua ketika anak menyelesaikan proses penyelesaian tugas. Ini diselesaikan oleh PI untuk mengurangi dampak negatif di luar tugas online.

Ada beberapa sikap yang dapat diterapkan untuk memiliki pilihan untuk ditanamkan pada anak-anak, melalui arahan dan kerjasama antara orang tua wali dan pengajar dalam pembelajaran daring, sehingga mereka secara tidak langsung siap memberikan dorongan dan energi kepada anak-anak. Berdasarkan hal ini, peneliti membagi penemuan-penemuan tersebut sebagai berikut:

\section{Pengarahan Orang Tua dan pengajar}

Arahan yang dilakukan pada anak-anak saat melakukan usaha yang intens harus didasarkan pada partisipasi orang tua wali dan pendidik untuk membuat hubungan damai yang sepenuhnya bertujuan untuk memberdayakan dan membangunkan semangat anak-anak yang sedang belajar.

\section{Dorongan dalam Belajar}

Anak-anak yang saat ini memiliki semangat belajar yang tinggi akan selalu bersemangat dan fokus saat mengerjakan tugas tanpa diminta oleh orang tuanya. Dorongan untuk anak-anak dalam melakukan apa yang diberikan pengajar sangat dibutuhkan. Dorongan pada anak-anak atau kebebasan dalam belajar sangat dipengaruhi oleh kondisi di sekitar anak itu.

\section{Latar belakang dan Pekerjaan Orang tua wali}

Latar belakang pendidikan dan pekerjaan orang tua wali sangat mempengaruhi motivasi belajar anakanak. orang tua dengan dasar pendidikan yang tinggi terikat untuk menerapkan kecenderungan terkendali saat belajar daring sehingga sangat mempengaruhi anak-anak. Orang tua yang memiliki daya ajar yang rendah berusaha mengabaikan anak-anaknya saat belajar daring karena pekerjaan yang menuntut kerja dari pagi hingga sore sehingga kurang siap mengawasi anak-anak dalam membiasakan membawa motivasi belajar anak-anak yang berkurang. (Yulianingsih et al., 2020) mengungkapkan bahwa inklusi orang tua sangat penting mengingat pengaruhnya terhadap keberhasilan anak.

Berdasarkan penjelasan tersebut, dapat disimpulkan bahwa ada beberapa hal yang dapat mempengaruhi motivasi belajar anak, lebih spesifiknya yaitu : (1) arahan orang tua dan pendidik, (2) dorongan anak dalam belajar, (3) latar belakang dan pekerjaan orang tua. Unsur-unsur tersebut, jika dapat dijalankan secara ideal, akan menjadi motivasi belajar anak yang hebat. 
3187 Penggunaan Gawai pada Pembelajaran Daring terhadap Motivasi Belajar Anak di Sekolah Dasar Lia Lutviana,Ika Ari Pratiwi, Imaniar Purbasari

DOI: https://doi.org/10.31004/edukatif.v3i5.1236

\section{KESIMPULAN}

Pembelajaran daring yang diterapkan pada anak-anak usia sekolah dasar di Desa Talun dilakukan dengan memanfaatkan gawai. Pelaksanaan pembelajaran daring membutuhkan sebuah aplikasi yang dapat menjaga kelancaran komunikasi antara anak-anak dan pengajar. Pemanfaatan gawai yang dapat dimanfaatkan dalam pembelajaran daring untuk anak usia SD di Desa Talun adalah Handphone (Hp), dengan bantuan aplikasi whatsapp dan google classroom. Pemanfaatan gawai selama pembelajaran daring dapat memiliki konsekuensi positif dan negatif pada otivasi belajar anak. Kajian pemanfaatan gawai pada motivasi belajar anak sangat dipengaruhi oleh perkembangan pribadi anak melalui pengelolaan pemanfaatan alat dan bantuan orang tua dengan pembelajaran daring. Bantuan orang tua untuk anak-anak ketika belajar online sangat penting karena akan menjadi kebiasaan dan pengembangan karakter untuk anak-anak. Hasil pertemuan yang diarahkan oleh para ahli mengungkapkan bahwa pekerjaan dan tingkat pendidikan wali atau orang tua sangat memengaruhi perkembangan motivasi belajar anak. Wali atau orang tua yang berfungsi sebagai visioner bisnis dan pedagang dapat berkonsentrasi pada anak-anak mereka karena mereka dapat bekerja di rumah dan memiliki energi yang cukup untuk anak-anak mereka. Sementara itu, wali atau orang tua yang berperan sebagai pekerja atau buruh membutuhkan pertimbangan dan arahan bagi anak-anak ketika belajar online, sehingga motivasi anak-anak akan berkurang. Pembelajaran daring menggunakan handphone, menjadikan kondisi motivasi belajar anak-anak harus dipikirkan. Karena motivasi belajar yang rendah adalah tidak tercapainya tujuan pembelajaran daring.

\section{UCAPAN TERIMA KASIH}

Dengan ini penulis mengucapkan terima kasih kepada anak-anak usia SD di Desa Talun, orang tua anak di Desa Talun, dan Guru kelas VI, V dan VI di SDN Talun 01 Kecamatan Kayen Kabupaten Pati yang telah memberikan ijin dan membantu pelaksanaan penelitian ini hingga selesai.

\section{DAFTAR PUSTAKA}

-, S., \& -, P. (2019). Upaya Meningkatkan Motivasi Belajar Siswa. G-Couns: Jurnal Bimbingan Dan Konseling, 3(1), 73-82. Https://Doi.Org/10.31316/G.Couns.V3i1.89

Anugrahana, A. (2020). Hambatan, Solusi Dan Harapan: Pembelajaran Daring Selama Masa Pandemi Covid19 Oleh Guru Sekolah Dasar. Scholaria: Jurnal Pendidikan Dan Kebudayaan, 10(3), 282-289. Https://Doi.Org/10.24246/J.Js.2020.V10.I3.P282-289

Chusna, P. A. (2017). Pengaruh Media Gadget Pada Perkembangan Karakter Anak. Dinamika Penelitian: Media Komunikasi Sosial Keagamaan, 17(2), 315-330. Https://EResources.Perpusnas.Go.Id:2093/Doi/Abs/10.1142/S0192415x20500500

Darmawati, J. (2017). Pengaruh Motivasi Belajar Dan Gaya Belajar Terhadap Prestasi Belajar Ekonomi Siswa Sma Negeri Di Kota Tuban. Jurnal Ekonomi Pendidikan Dan Kewirausahaan, 1(1), 79. Https://Doi.Org/10.26740/Jepk.V1n1.P79-90

Firyal, R. A. (2020). Pembelajaran Daring Dan Kebijakan New Normal Pemerintah. Lawarxiv Papers, 1-7. Https://Osf.Io/Preprints/Lawarxiv/Yt6qs/

Hanafi, A. (2020). Kecenderungan Anak Bermain Gawai Hubungannya Dengan Motivasi Dan Prestasi Belajar. Edubase: Journal Of Basic Education, 1(1), 30-40.

Kurniawati, D. (2020). Pengaruh Penggunaan Gadget Terhadap Prestasi Siswa. Edukatif: Jurnal Ilmu Pendidikan, 2(1), 78-84. Https://Doi.Org/10.31004/Edukatif.V2i1.78

Lee, J., \& Martin, L. (2017). Investigating Students' Perceptions Of Motivating Factors Of Online Class 
3188 Penggunaan Gawai pada Pembelajaran Daring terhadap Motivasi Belajar Anak di Sekolah Dasar Lia Lutviana,Ika Ari Pratiwi, Imaniar Purbasari

DOI: https://doi.org/10.31004/edukatif.v3i5.1236

Discussions. International Review Of Research In Open And Distributed Learning. International Review Of Research In Open And Distributed Learning, 18(5), 148-172. Https://Www.Erudit.Org/En/Journals/Irrodl/1900-V1-N1-Irrod104896/1064907ar/Abstract/

Lestari, I., Riana, A. W., \& Taftazani, B. M. (2015). Pengaruh Gadget Pada Interaksi Sosial Dalam Keluarga. Prosiding Penelitian Dan Pengabdian Kepada Masyarakat, 2(2), 204-209. Https://Doi.Org/10.24198/Jppm.V2i2.13280

Marpaung, J. (2018). Pengaruh Penggunaan Gadget Dalam Kehidupan. Kopasta: Jurnal Program Studi Bimbingan Konseling, 5(2), 55-64. Https://Doi.Org/10.33373/Kop.V5i2.1521

Miftahussaadah, M., \& Subiyantoro, S. (2021). Paradigma Pembelajaran Dan Motivasi Belajar Siswa. Islamika, 3(1), 97-107. Https://Doi.Org/10.36088/Islamika.V3i1.1008

Radliya, N. R., Apriliya, S., \& Zakiyyah, T. R. (2017). Pengaruh Penggunaan Gawai Terhadap Perkembangan Sosial Emosional Anak Usia Dini. Jurnal Paud Agapedia, 1(1), 1-12. Https://Doi.Org/10.17509/Jpa.V1i1.7148

Rijali, A. (2019). Analisis Data Kualitatif. Alhadharah: Jurnal Ilmu Dakwah, 17(33), 81. Https://Doi.Org/10.18592/Alhadharah.V17i33.2374

Rosiyanti, H., \& Muthmainnah, R. N. (2018). Penggunaan Gadget Sebagai Sumber Belajar Mempengaruhi Hasil Belajar Pada Mata Kuliah Matematika Dasar. Fibonacci: Jurnal Pendidikan Matematika Dan Matematika, 4(1), 25. Https://Doi.Org/10.24853/Fbc.4.1.25-36

Santika, I. W. E. (2020). Pendidikan Karakter Pada Pembelajaran Daring. Indonesian Values And Character Education Journal, 3(1), 8-19.

Santoso, F. A. (2020). Dampak Penggunaan Gawai Terhadap Pembelajaran Siswa Sekolah Dasar. Edukatif: Jurnal Ilmu Pendidikan, 2(1), 49-54. Https://Doi.Org/10.31004/Edukatif.V2i1.87

Syarifudin, A. S. (2020). Impelementasi Pembelajaran Daring Untuk Meningkatkan Mutu Pendidikan Sebagai Dampak Diterapkannya Social Distancing. Jurnal Pendidikan Bahasa Dan Sastra Indonesia Metalingua, 5(1), 31-34. Https://Doi.Org/10.21107/Metalingua.V5i1.7072

Trinova, Z. (2012). Hakikat Belajar Dan Bermain Menyenangkan Bagi Peserta Didik. Al-Ta Lim Journal, 19(3), 209-215. Https://Doi.Org/10.15548/Jt.V19i3.55

Yulianingsih, W., Suhanadji, S., Nugroho, R., \& Mustakim, M. (2020). Keterlibatan Orangtua Dalam Pendampingan Belajar Anak Selama Masa Pandemi Covid-19. Jurnal Obsesi : Jurnal Pendidikan Anak Usia Dini, 5(2), 1138-1150. Https://Doi.Org/10.31004/Obsesi.V5i2.740

Yunitasari, R., \& Hanifah, U. (2020). Pengaruh Pembelajaran Daring Terhadap Minat Belajar Siswa Pada Masa Covid 19. Edukatif: Jurnal Ilmu Pendidikan, 2(3), 232-243. Https://Doi.Org/10.31004/Edukatif.V2i3.142 